\title{
PERLINDUNGAN HUKUM TERHADAP TERTANGGUNG ATAS HAK - HAK NYA DARI PERUSAHAAN ASURANSI YANG PAILIT BERDASARKAN PUTUSAN PENGADILAN NIAGA*
}

\author{
Oleh : \\ I Nyoman Gede Gita Mahardika** \\ A.A. Sagung Wiratni Darmadi, S.H., M.H. ${ }^{* * *}$ \\ Program Kekhususan Huku Bisnis, Fakultas Hukum, \\ Universitas Udayana
}

\begin{abstract}
ABSTRAK
Dalam penulisan skripsi ini berjudul Perlindungan Hukum Terhadap tertanggung Atas Hak-Hak-nya Dari Perusahaan Asuransi Yang Pailit Berdasarkan Putusan Pengadilan Niaga dengan perumusan masalah 1. Bagaimana akibat putusan pailit terhadap perusahaan asuransi yang dinyatakan pailit dan 2 . Bagaimana perlindungan hukum atas hak-hak tertanggung menurut Undang-Undang Kepailitan dan Undang-Undang Perasuransian.

Hasil penelitian menunjukan akibat putusan pailit terhadap perusahaan asuransi sebagai debitur yang telah dinyatakan pailit maka debitur pailit demi hukum kehilangan haknya secara keperdataan untuk menguasai dan mengurus kekayaan yang termasuk dalam harta pailit, sejak tanggal putusan pernyataan pailit diucapkan, akibat putusan pailit selanjutnya adalah terhadap seluruh perikatan yang dibuat debitur pailit dalam Pasal 25 UndangUndang Nomor 37 Tahun 2004 menentukan bahwa semua perikatan debitur yang timbul setelah adanya putusan pailit, tidak lagi dapat dibayar dari harta pailit kecuali perikatan tersebut menguntungkan harta pailit. Adanya perbedaan pengaturan antara undang-undang Nomor 40 tahun 2014 dan Undang-Undang Nomor 37 tahun 2004 maka berlaku sesuai asas hukum lex specialis derogate legi generalis dalam Undang-Undang Nomor 37 tahun 2004 sehingga UndangUndang Nomor 40 Tahun 2014 mengesampingkan Undang-Undang

\footnotetext{
* Jurnal ini diambil dari intisari skripsi yang berjudul Perlindungan Hukum Terhadap tertanggung Atas Hak-Hak nya Dari Perusahaan Asuransi Yang Pailit Berdasarkan Putusan Pengadilan Niaga**

** I Nyoman Gede Gita Mahardika adalah Mahasiswa Fakultas Hukum Univesitas Udayana, gitamahardika777@gmail.com

${ }^{* * *}$ A.A. Sagung Wiratni Darmadi adalah dosen Fakultas Hukum Universitas Udayana
} 
Nomor 37 tahun 2004 yang menjadikan kedudukan tertanggung lebih diutamakan (kreditur preferen).

Kata Kunci : Perlindungan Hukum, Tertanggung, Kepailitan

\begin{abstract}
In writing this essay entitled Legal Protection of the Insured on his Rights From Bankrupt Insurance Company Based on the Decision of the Commercial Court with the formulation of the problem 1. What is the effect of the bankruptcy decision on the insurance company declared bankrupt and 2. What is the legal protection of the insured's rights according to Bankruptcy Law and Insurance Law.

The results of the study show the effect of bankruptcy decisions on insurance companies as debtors who have been declared bankrupt, bankrupt debtors legally lose their civil rights to control and manage assets included in bankrupt assets, from the date the bankruptcy statement is pronounced, as a result of the subsequent bankruptcy decision. made by the bankrupt debtor in Article 25 of Law Number 37 of 2004 stipulates that all debtor agreements arising after the bankruptcy decision are no longer payable from bankrupt assets unless the agreement benefits bankrupt assets. The difference in regulation between law number 40 of 2014 and law number 37 of 2004 applies according to the legal principle of lex specialis derogate legi generalis in Law Number 37 of 2004 so that Law Number 40 of 2014 overrides the Law Number 37 of 2004 which makes the position of the insured preferred (preferred creditor).
\end{abstract}

Keywords: Legal Protection, Insured, Bankruptcy

\title{
I. PENDAHULUAN
}

\subsection{Latar Belakang}

Perkembangan ekonomi dunia turut memperketat persaingan antara perusahaan asuransi dalam perebutan pangsa pasar. Asuransi merupakan suatu lembaga keuangan bukan bank yang semakin mendapatkan tempat di dalam masyarakat, baik dilihat dari sisi pengusaha maupun dari sisi kebutuhan masyarakat, bahkan hampir dalam setiap hal harus berurusan dengan pertanggungan. 
Undang - Undang No. 40 Tahun 2014 tentang Perasuransian Pasal 6 ayat (1) menyebutkan bahwa bentuk badan hukum penyelenggara Usaha Perasuransian adalah: Perusahaan Perseroan (Persero), Koperasi, Usaha Bersama yang telah ada pada saat Undang - Undang ini digunakan. Tentunya di dalam menjalankan kegiatan usahanya perusahaan-perusahaan tersebut dapat mengalami resiko yaitu seperti resiko mengalami pailit,

Di Indonesia, krisis moneter pernah terjadi ketika pertengahan Tahun 1997 sampai Tahun 1998 lalu. Dimana akibat dari krisis ini yaitu banyaknya perusahaan-perusahaan pada saat itu mengalami kepailitan yang diakibatkan ketidakmampuan dari perusahaan tersebut untuk melunasi utang-utangnya yang sudah jatuh tempo. Untuk mengatasi kondisi negara dan pemerintahan yang seperti ini, serta memberi suatu jaminan perlindungan yang pasti terhadap para investor asing juga lokal, maka perlu dibuat suatu peraturan yang dapat menjadi sarana hukum sebagai solusinya, baik bagi pihak debitur sendiri maupun bagi pihak krediturnya. Peraturan itu adalah Undang-Undang Nomor 4 Tahun 1998 Tentang Penetapan Peraturan Pemerintah Pengganti Undang-Undang Nomor 1 Tahun 1998 Tentang Perubahan Atas Undang-Undang Tetang Kepailitan Menjadi Undang-Undang. Seiring dengan perkembangan Hukum Kepailitan dan kebutuhan masyarakat yang selalu bergerak dinamis, UndangUndang Nomor 4 Tahun 1998 tentang Kepailitan diubah menjadi Undang-Undang Nomor 37 Tahun 2004 tentang Kepailitan dan Penundaan Kewajiban Pembayaran Utang yang selanjutnya disebut dengan Undang - Undang Nomor 37 Tahun 2004 tentang Kepailitan dan PKPU disahkan dan diundangkan tanggal 18 Oktober 2004. 
Dengan melihat latar belakang diatas, maka dirasa sangat perlu diadakannya penelitian lebih lanjut terkait permasalahan apabila suatu perusahaan asuransi mengalami kepailitan, maka hak dan kewajiban untuk mengurusi dan menguasai kekayaan yang termasuk harta pailit sudah tidak ada pada perusahaan asuransi. Hal ini tentu menimbulkan kekhawatiran bagi para tertanggung untuk mendapatkan hak-haknya dari perusahaan asuransi yang dinyatakan pailit. Yang dalam hal ini terdapat konflik norma dimana dalam Undang-Undang Nomor 37 Tahun 2004 tentang Kepalitan dan PKPU banyak menyinggung pengembalian atau pembayaran utangutang kepada kreditornya tetapi tidak secara eksplisit menyinggung kedudukan Tertanggung atau pemegang polis asuransi sebagai kreditor preferen, beda hal nya dengan Undang - Undang Nomor 40 Tahun 2014 tentang Perasuransian didalam satu pasalnya, yakni Pasal 52 ayat (1) mengatur dengan tegas bahwa hak pemegang polis atau Tertanggung atas pembagian kekayaan perusahaan asuransi yang dipailitkan atau dilikuidasi mempunyai kedudukan lebih tinggi (preferen) dari hak kreditor lainnya, Maka dari itu diperlukan adanya perlindungan hukum pasti yang melindungi kedudukan Tertanggung atas hak-haknya apabila suatu perusahaan asuransi dinyatakan pailit

\subsection{Rumusan Masalah}

Berdasarkan uraian latar belakang diatas, adapun yang menjadi rumusan masalah dalam karya ilmiah ini adalah sebagai berikut berikut:

1. Bagaimana perlindungan hukum bagi tertanggung dalam kepailitan perusahaan asuransi? 
2. Bagaimana kedudukan pemegang polis dalam perusahaan asuransi apabila perusahaan asuransi dinyatakan pailit?

\subsection{Tujuan Penelitian}

Tujuan khusus dari penelitian dan penulisan karya ilmiah ini adalah:

1. Untuk mengetahui perlindungan hukum bagi tertanggung apabila suatu perusahaan asuransi dinyatakan pailit.

2. Untuk mengetahui kedudukan pemegang polis dalam perusahaan asruansi yang dinyatakan pailit.

\section{ISI MAKALAH}

\subsection{Metode Penelitian}

Jenis penelitian yang digunakan dalam penulisan skripsi ini termasuk ke dalam penelitain normatif, karena penelitian ini mengkaji Perundang-Undangan yang berlaku. Menurut Abdulkadir Muhammad, fokus penelitian hukum normatif adalah penelitan hukum yang mengkaji hukum tertulis dari berbagai aspek yaitu aspek teori, sejarah, filosofi, perbandingan, struktur dan komposisi, lingkup dan materi, konsistensi, penjelasan umum pasal demi pasal, formalitas dan kekuatan mengikat serta UU, serta bahan hukum yang digunakan, tetapi tidak mengkaji aspek terapan atau implementasinya, maka penelitian hukum normatif sering juga disebut "penelitian hukum dogmatic" atau "penetian hukum teoritis" (dogmatic theoretical law search $)^{1}$

\subsection{Hasil Pembahasan}

\subsubsection{Perlindungan hukum bagi tertanggung dalam kepilitan perusahaan asuransi}

\footnotetext{
${ }^{1}$ Abdulkadir Muhammad, 2004, Hukum dan Penelitain Hukum, PT. Citra Aditya Bakti, Bandung, h. 40.
} 


\section{- Undang-Udang Kepailitan}

Dalam peraturan kepailitan tidak ada tercantum secara tegas dan jelas defenisi dari "pailit". Meskipun begitu, dapat diketahui arti kata "pailit" secara etimologi, yaitu pailit artinya jatuh miskin, bangkrut. ${ }^{2}$ istilah bankrupt adalah seorang pedagang yang merahasiakan dirinya sendiri, ataupun melakukan tindakantindakan lain yang cenderung mengelabuhi krediturnya. Asal mula dari pengertian dan pemakaian kata "bangkrut" berasal dari praktekpraktek yang dilakukan para pemberi pinjaman di Venesia (Italia) pada waktu lalu.dimana banco (bangku) dari seorang banker yang tidak mampu membayar atau gagal dalam usahanya telah benarbenar patah atau hancur. ${ }^{3}$

Syarat kepailitan sederhana, yaitu dengan cukup adanya dua kreditor dan ada utang yang telah jatuh tempo kreditor dapat mengajukan pailit tentu dapat menimbulkan masalah, karena persoalan kepailitan itu bukan saja menyangkut kepentingan perusahaan semata, tetapi juga kepentingan sosial. Permohonan pernyataan pailit oleh kreditor tidak dilakukan atas dasar masalah sehat tidaknya keuangan debitor, tetapi sebagai sarana penyelesaian masalah perdata yang tidak terselesaikan. ${ }^{4}$

Didalam Pasal 2 ayat (5) Undang-Undang Nomor 37 tahun 2004 menyinggung masalah kepailitan perusahaan asuransi, tetapi dalam pasal-pasal berikutnya tidak ditemukan pasal yang menyinggung perihal kedudukan pemegang polis asuransi apakah

\footnotetext{
${ }^{2}$ Peter Salim dan Yenny Salim, 2002, Kamus Bahasa Indonesia Kontenporer, Ed. Ketiga, Modern English Press, Jakarta, h. 1076.

${ }^{3}$ Munir Fuady, 2003, Hukum Perusahaan Dalam Paradigma hukum Bisnis, PT. Citra Aditya Bakti, Bandung, h. 196.

${ }^{4}$ Siti Anisah, 2008, Perlindungan Kepentingan Kreditor dan Debitor Dalam Hukum Kepailitan di Indonesia, Total Media, Yogyakarta, h. 14
} 
preferen atau kreditur konkuren. bahkan tetap mempertahankan konsep perlindungan hukum yang dianut oleh pasal 1133 KUHPerdata yang menempatkan kreditur pemegang jaminan kebendaan seperti pemegang gadai, hipotik, termasuk hak tanggungan dan jaminan fidusia sebagai kreditur separatis yang pembayaran hak-hak diutamakan, walaupun hak-hak tersebut baru bias direalisasikan setelah melewati masa penundaan lebih kurang 90 hari. Bila demikian jelas bahwa tertanggung masih merupakan kreditur biasa yang harus bersaing mendapatkan pemenuhan tagihan (hak) dengan kreditur-kreditur konkuren lainnya, namun setelah kurator menyelesaikan pembayaran kepada kreditur yang tergolong istimewa dan separatis. ${ }^{5}$ Pada dasarnya dampak implementasi Undang-Undang Nomor 37 Tahun 2004, tidak mengatur ketentuan khusus atau aturan khusus atau pemberian hak khusus pada perusahaan asuransi dalam kasus-kasus penyelesaian kepailitan yang menyangkut debiturnya adalah sebauh perusahaan asuransi. Karena, kalau dilihat dari karakteristik asuransi itu sendiri adalah sebuah usaha jasa yang menyangkut langsung dengan kepentingan orang banyak, sehingga dengan demikian dalam kasus kepailitan perusahaan asuransi pada akhirnya menemui jalan buntu akibat adanya ketidakpastian hukum dan ketidakjelasan tentang kepailitan sebuah perusahaan asuransi yang sudah jelas akibat putusan pailit yang diletakkan pada perusahaan asuransi akan membawa dampak yang luas dengan mengingat kepentingan para konsumen asuransi, yaitu para

\footnotetext{
${ }^{5}$ Mulhadi, kedudukan tertanggung dalam kepailitan asuransi, jurnal, fakultas hukum Universitas Sumatera Utara 2009, hlm. 17, diakses pada http://repository.usu.ac.id pada tanggal 19 November 2018.
} 
pemegang polis sebagai pihak yang paling merasakan dampak tersebut. ${ }^{6}$

\section{- Undang-Undang Perasuransian}

Pengertian Asuransi sudah disebutkan dalam Kitab UndangUndang Hukum Dagang Pasal 246 bahwa asuransi atau pertanggungan adalah perjanjian, dimana penanggung mengikat diri terhadap tertanggung dengan memperoleh premi, untuk memberikan kepadanya ganti rugi karena suatu kehilangan, kerusakan, atau tidak mendapat keuntungan yang diharapkan, yang mungkin akan dapat diderita arena suatu peristiwa yang tidak pasti.

Secara umum perusahaan yang bergerak bidang perasuransian adalah perusahaan yang berbadan hukum perseroan. Perseroan sebagai badan hukum tidak dapat bertindak sendiri untuk menjalankan kegiatannya sesuai dengan maksud dan tujuannya dibentuknya perseroan, maka dibentuklah organ perseroan sesuai dengan perintah undang-undang. ${ }^{7}$

Dalam Undang-Undang Nomor 40 tahun 2014 tentang perasuransian didalam salah satu pasalnya yakni Pasal 52 ayat (1) mengatur dengan tegas bahwa hak pemegang polis, tertanggung atau peserta asuransi atas pembagian kekayaan perusahaan perasuransian yang dipailitkan atau dilukidasi mempunyai kedudukan lebih tinggi (utama) dari pihak kreditur lainnya

\subsubsection{Kedudukan tertanggung dalam perusahaan asuransi yang dinyatakan pailit}

Kedudukan tertanggung dilihat dalam KUHPerdata semua kreditur pada dasarnya mempunyai kedudukan yang sama.

\footnotetext{
${ }^{6}$ Adrian Sutedi, Hukum Kepailitan, Ghalia Indonesia, Jakarta, 2009, hlm 132

${ }^{7}$ Syamsudin M. Sinaga, Hukum Kepailitan Indonesia, Tatanusa, Jakarta, 2012, h 145.
} 
Pelunasan utang dengan sendiri dibagi menurut asas kesimbangan yaitu berdasarkan besar-kecilnya jumlah piutang masing-masing kreditur, hal ini ditegaskan dalam Pasal 1132 KUHPerdata yang menyatakan bahwa kebendaan tersebut menjadi jaminan bersamasama bagi semua orang yang mepunyai piutang kepadanya, pendapatan dari penjualan benda-benda itu dibagi menurut keseimbangan yaitu menurut besar-kecilnya piutang masing-masing, kecuali apabila suara kreditur mempunyai alas an-alasan yang sah untuk didahulukan. ${ }^{8}$

Dalam Undang-Undang Nomor 37 tahun 2004 tentang Kepailitan dan PKPU banyak menyinggung tentang pengembalian utang-utang debitur kepada krediturnya namun Undang-Undang kepailitan tidak secara eksplisit menyinggung kedudukan tertanggung atau pemegang polis asuransi sebagai salah satu kreditur yang hak-haknya diutamakan (preferen), bahkan tetap mempertahankan konsep perlindungan hukum yang dianut oleh pasal 1133 KUHPerdata yang menempatkan kreditur pemegang jaminan kebendaan seperti pemegang gadai, hipotik, termasuk hak tanggungan dan jaminan fidusia sebagai kreditur separatis yang pembayaran hak-haknya diutamakan.

Menurut ketentuan Pasal 56 ayat (2) Undang-Undang Kepailitan lama atau Pasal 55 ayat (2) Undang-Undang Kepailitan baru, piutang para pemegang polis asuransi bisa dieksekusi langsung, seperti layaknya piutang para kreditor separatis atau yang diistimewakan. Melaikan piutang tersebut baru bisa dibayarkan setelah melalui proses pencocokan utang piutang yang batas waktunya ditentukan oleh Hakim Pengawas. Dengan kata lain,

\footnotetext{
${ }^{8}$ opcit, hal. 13
} 
pembayaran piutang kepada para nasabah asuransi (Tertanggung) baru dibayarkan setelah Kurator atau BHP menuntaskan proses pembayaran kepada para kreditor yang diutamakan.

Menurut Pasal 127 Undang-Undang Kepailiatan lama atau Pasal 137 Undang-Undang Kepailitan baru, piutang Tertanggung tersebut bisa dikelompokan sebagai jenis piutang yang saat penagihannya belim jelas atau yang memberikan hak untuk memperoleh pembayaran secara berkala. Demikan juga, bisa dikelompokkan sebagai jenis piutang yang dapat ditagih dalam waktu (satu) tahun atau yang dapat ditagih setelah lewat (satu) tahun setelah tanggal putusan pernyataan pailit diucapkan. Hal ini berkaitan dengan saat jatuh tempo polis yang dimiliki oleh Tertanggung.

Seorang Tertanggung yang polis asuransinya belum jatuh tempo atau evenemen-nya belum terjadi, ketika putusan pernyataan pailit dibacakan, maka piutangnya bisa dikelompokkan sebagai piutang yang saat penagihannya belum jelas.Sedangkan Tertanggung yang memegang polis asuransi pendidikan misalnya, bisa dikelompokkan sebagai piutang yang pembayarannya dilakukan secara berkala, maka nilai tagihannya wajib dicocokkan pada saat putusan pailit dibacakan. Tetapi, bisa juga piutang Tertanggung asuransi termasuk golongan piutang, sebagimana dimaksud dalam Pasal 137 ayat (2) dan (3) bila posisinya memang baru jatuh tempo satu tahun atau setelah satu tahun setelah putusan pernyataan pailit diucapkan. Namun yang jelas, hak-hak atau piutang Tertanggung asuransi kedudukannya merupakan kreditor konkuren atau bersaing. 
Dan dalam ketentuan Undang-Undang Nomor 40 Tahun 2014 tentang perasuransian disalah satu pasalnya yakni Pasal 52 ayat (1) mengatur dengan tegas bahwa hak pemegang polis, tertanggung atau peserta asuransi atas pembagian kekayaan perusahaan asuransi yang di pailitkan ayau di likuidasi mempunyai kedudukan lebih tinggi (utama dari hak kreditor lainnya). Pasal dimaksud secara lengkap berbunyi sebagai berikut: "Dalam hal perusahaan asuransi, perusahaan asuransi syariah, perusahaan reasuransi, atau perusahaan reasuransi syariah dipailitkan atau di likuidasi, hak pemegang polis, tertanggung atau peserta atas pembagian harta kekayaan mempunyai kedudukan lebih tinggi dari pihak lainnya.

Bila ketentuan dalam Undang-Undang Perasuransian ini dihadapkan dengan Undang-Undang Kepailitan dan PKPU, keduanya tampak tidak sejalan. Ada pendapat yang menyatakan, bahwa untuk Tertanggung yang pembayaran premi asuransinya telah jatuh tempo dan berhak atas pembayaran klaim asuransi, maka Tertanggung yang bersangkutan menempati kedudukan sebagai kreditor diutamakan (preferen), sedangkan bagi Tertanggung yang belum berhak atas pembayaran klaim asuransi, baik secara polisnya belum jatuh tempo atau peristiwanya (evenemen) belum terjadi, maka kedudukannya adalah sebagai kreditor biasa (konkuren).

Perbedaan pengaturan ini dapat menyebabkan kebingungan dalam hal penyelesaian perkara kepailitan perusahaan asuransi atau pemberesan harta kepailitan perusahaan asuransi. meskipun tidak diatur tentang kedudukan pemegang polis dalam KUHPerdata dan Undang-Undang Nomor 37 tahun 2004, akan tetapi Pasal 52 ayat (1) Undang-Undang Nomor 40 Tahun 2014 tersebut berlaku sesuai asas hukum lex specialis derogate legi generalis dalam KUHPerdata dan 
Undang-Undang Nomor 37 tahun 2004. Artinya ketentuan hukum khusus dapat mengesampingkan ketentuan hukum umum. Sehingga pasal 52 ayat (1) Undang-Undang Nomor 40 Tahun 2014 berlaku dalam perkara kepailitan perusahaan asuransi karena undangundang ini merupakan ketentuan hukum khusus yang berlaku untuk perusahaan asuransi yang menempatkan kedudukan pemegang polis sebagai kreditur preferen yang hak pembayarannya diutamakan dan Undang-Undang Nomor 37 Tahun 2004 serta KUHPerdata yang berlaku secara umum yang menempatkan kedudukan pemegang polis sebagai kreditur konkuren meskipun tidak secara tegas diatur harus dikesampingkan atau tunduk pada ketentuan Undang-Undang Nomor 40 Tahun 2014 yang berlaku secara khusus ini

\section{PENUTUP}

\subsection{Kesimpulan}

1. Bahwa perlindungan hukum terhadap tertanggung atas hakhaknya apabila terjadi kepailitan pada suatu perusahaan asuransi, tertanggung atau pemegang polis tidak diatur secara tegas perlindungan hukumnya, Undang-Undang Kepailitian banyak menyinggung perihal masalah kepailitan perusahaan asuransi tapi dalam pasal-pasalnya tidak ditemukan menyinggung perihal kedudukan pemegang polis asuransi apakah preferen atau kreditur konkuren. Namun dalam Undang-Undang Perasuransian secara tegas mengatur perlindungan hukum dalam salah satu pasalnya yakni Pasal 52 ayat (1).

2. Kedudukan tertanggung dalam Undang-Undang Kepailitan menempatkan tertanggung sebagai keditur biasa (konkuren) yang harus bersaing mendapatkan pemenuhan haknya dengan kreditur 
konkuren lainnya, namun setelah kurator menyelesaikan pembayaran kepada para kreditur yang istimewa (privilege) dan separatis. Namun dalam Undang-Undang Perasuransian kedudukan tertanggung mempunyai kedudukan lebih tinggi dari kreditur lainnya, dimana diatur di dalam Pasal 52 ayat (1) Undang-Undang Nomor 40 tahun 2014 tentang Perasuransian. Perbedaan pengaturan ini dapat menyebabkan kebingungan dalam hal penyelesaian perkara kepailitan perusahaan asuransi atau pemberesan harta kepailitan perusahaan asuransi, meskipun tidak diatur tentang kedudukan pemegang polis dalam UndangUndang Nomor 37 tahun 2004, akan tetapi Pasal 52 ayat (1) Undang-Undang Nomor 40 Tahun 2014 tersebut berlaku sesuai asas hukum lex specialis derogate legi generalis dalam KUHPerdata dan Undang-Undang Nomor 37 tahun 2004. Artinya ketentuan hukum khusus dapat mengesampingkan ketentuan hukum umum. Sehingga pasal 52 ayat (1) Undang-Undang Nomor 40 Tahun 2014 berlaku dalam perkara kepailitan perusahaan asuransi karena undang-undang ini merupakan ketentuan hukum khusus yang berlaku untuk perusahaan asuransi yang menempatkan kedudukan pemegang polis sebagai kreditur preferen yang hak pembayarannya diutamakan dan UndangUndang Nomor 37 Tahun 2004 serta KUHPerdata yang berlaku secara umum yang menempatkan kedudukan pemegang polis sebagai kreditur konkuren meskipun tidak secara tegas diatur harus dikesampingkan atau tunduk pada ketentuan UndangUndang Nomor 40 Tahun 2014 yang berlaku secara khusus ini 


\subsection{Saran}

1. Seharusnya perlindungan hukum bagi tertanggung harus secara tegas diatur dalam undang-undang kepailitan dan PKPU demi melindungi hak-hak yang seharusnya didapat oleh pihak tertanggung apabila suatu perusahaan asuransi mengalami kepailitan.

2. Kedudukan tertanggung seharusnya diutamakan dan diatur dengan jelas dalam undang-undang kepailitan agar penyelesaian perkara kepailitan dan pemberesan harta pailit perusahaan asuransi mengacu kepada tertanggung.

\section{Daftar Pustaka}

\section{Buku}

Abdulkadir Muhammad, 2004, Hukum dan Penelitain Hukum, PT. Citra Aditya Bakti, Bandung.

Adrian Sutedi, 2009, Hukum Kepailitan, Ghalia Indonesia, Jakarta.

Munir Fuady, 2003, Hukum Perusahaan Dalam Paradigma hukum Bisnis, PT. Citra Aditya Bakti, Bandung

Peter Salim dan Yenny Salim, 2002, Kamus Bahasa Indonesia Kontenporer, Ed. Ketiga, Modern English Press, Jakarta

Siti Anisah, 2008, Perlindungan Kepentingan Kreditor dan Debitor Dalam Hukum Kepailitan di Indonesia, Total Media, Yogyakarta

Syamsudin M. Sinaga, 2012, Hukum Kepailitan Indonesia, Tatanusa, Jakarta. 


\section{Artikel}

Mulhadi, kedudukan tertanggung dalam kepailitan asuransi, jurnal, fakultas hukum Universitas Sumatera Utara 2009, hlm. 17, diakses pada http://repository.usu.ac.id pada tanggal 19 November 2018.

\section{Undang-Undang}

Kitab Undang-Undang Hukum Perdata, Burgerlijk Wetboek, 2014, Terjemahan Soedharyo Soimin, Sinar Grafika, Jakarta.

Indonesia, Undang-Undang Nomor 8 Tahun 1999 tentang Perlindungan Konsumen, Lembaran Negara Republik Indonesia Tahun 1999 Nomor 42.

Indonesia, Undang-Undang Nomor 37 Tahun 2004 tentang Kepailitan dan Penundaan Kewajiban Pembayaran Utang, Lembaran Negara Republik Indonesia Tahun 2004 Nomor 131, Tambahan Lembaran Negara Republik Indonesia Nomor 3778

Indonesia, Undang-Undang Nomor 40 Tahun 2014 tentang Persuransian, Lembaran Negara Republik Indonesia Tahun 2014 Nomor 337, Tambahan Lembaran Negara Republik Indonesia Nomor 3467 